This article is (c) Emerald Group Publishing and permission has been granted for this version to appear here (http://epress.lib.uts.edu.au/research/handle/10453/10163). Emerald does not grant permission for this article to be further copied/distributed or hosted elsewhere without the express permission from Emerald Group Publishing Limited.' 
Influence and Power Dynamics in Client-Consultant Teams

\author{
NATALIA NIKOLOVA \\ University of Technology Sydney \\ School of Management \\ Australia \\ Phone: +61 295143645 \\ Fax: +61 295143602 \\ E-Mail: natalia.nikolova@uts.edu.au \\ TIMOTHY M. DEVINNEY \\ Professor of Strategy \\ Australian School of Business, UNSW \\ Australia \\ E-Mail: T.Devinney@agsm.edu.au
}

Published in the Journal for Strategy and Management 


\title{
Influence and Power Dynamics in Client-Consultant Teams
}

\begin{abstract}
Client-consultant interactions influence not only what is seen as relevant management knowledge but also how it is produced, legitimated, distributed and consumed. Although it has been recognized that client-consultant interactions are inherently political, the nature of power and the power dynamics in client-consultant teams are still poorly understood. Taking a differentiated look at the roles and responsibilities of members of client-consultant teams, we provide a micro perspective of power within client-consultant teams. We propose that two forms of power influence clientconsultant interactions: positional power, as expressed through the authority of the sponsor and the client project manager, and rhetorical power, expressed in the actions of consultants. While the outcome of the interplay of these forms of power is not predictable, which confirms the interdependent nature of power within client-consultant teams, we suggest that some members of the client team can find themselves in the position of the dependent, or "silenced", actor in the relationship. The paper concludes by assessing the practical and theoretical implications of our study.
\end{abstract}

Key words: strategic consulting, consultancy, client-consultant teams, power 


\section{Influence and Power Dynamics in Client-Consultant Teams}

“Social action depends on power just as physical movement depends on energy."

(Bennis et al. 1969: 153)

\section{Introduction}

Consulting companies and their clients are major players in the production and dissemination of management practices. Client-consultant interactions influence not only what is seen as relevant management knowledge but also how it is produced, legitimated, distributed and consumed (Suddaby and Greenwood 2001). Although there is considerable research on the nature and characteristics of these processes (Abrahamson 1996; Bloomfield and Best 1992; Kieser 2002; Suddaby and Greenwood 2001) acknowledging that power plays a significant part in the interaction between clients and consultants, the nature of power relations within client-consultant teams and how they influence the consulting process is still poorly understood.

The dominant view in the consulting literature is that consultants are powerful and clients powerless and dependent (Armbrüster 2006). The origin of consultant's power is either seen in the superiority of their knowledge (Haug and Sussman 1969; Kubr 1996; Sharma 1997; Mills and Moshavi 1999) or in the rhetoric and faddishness of consultant's language and concepts (Alvesson 1993, 2001; Clark 1995; Kieser 1997, 2002; Clark and Salaman 1998a, b). At the same time, it has been recognized that the consulting market is a buyers market, which gives clients considerable economic power vis-à-vis consultants (Armbrüster 2006; also Werr and Styhre 2003; Alvesson and Johansson 2002). In the professional services literature, this has been labeled "client capture" and refers to the economic dependency of professional service providers from their clients (e.g., Macey and Sale 2003; Gunz and Gunz 2008). Consequently, within the literature, "there is [] some ambivalence in regard to the power distribution in the [clientconsultant] relationship” (Werr and Styhre 2003: 44). 
The tendency toward a belief in a unidirectional dependence within client-consultant teams has been criticized strongly, independent of the orientation of that dependency. Fincham (1999) emphasizes that the interaction between the consultants' and the managers' knowledge contextualizes the level of dependency between both parties. Sturdy (1997b) points out that the client-consultant relationship is dialectic, where managers and consultants both play an active role. Suddaby and Greenwood (2001: 947) argue that neither clients nor consultants can solely determine the success or failure of given consulting project because management knowledge is produced in a "process of social construction and outcomes in the field are the product of interactions of diverse groups with different and often conflicting interests”. They further stress that more research is needed to explicate the role of actors in this process as well as their power relations. ${ }^{1}$ Other researchers stress that much of the existing research on consulting, and on knowledge transfer and learning in general, has tended to neglect or simplify issues of power and political activity (Armbrüster and Kieser, 2001; Coopey and Burgoyne 2000; Ferdinand 2004; Marshall and Rollinson 2004; Iding 2000). Moreover, existing research does not tell us much about how the ongoing political process influences interaction and problem solving within clientconsultant teams (e.g., Walsh and Fahey 1986).

Werr and Styhre who observed simultaneously “images of the dependent client, putting large responsibility in the hands of management consultants" and "images of the client in full control” (2003: 57), see an explanation in two different management discourses: the network discourse and the bureaucratic discourse. According to the former, clients have to cooperate closely with consultants if they are to help their organizations tackle different challenges. At the same time managers follow the bureaucratic discourse, regarding themselves as the actors in control who have to specify exactly the needed consulting services. The conclusion is that these contrasting

\footnotetext{
1 Suddaby and Greenwood (2001) discuss the process through which new management knowledge is created and disseminated from a macro perspective. In contrast, we look at this process from a micro perspective and pay special attention to the power dynamics within single client-consultant teams.
} 
perspectives and behavior of managers towards consultants are the reason for the ambiguous empirical findings and theoretical remarks of power in client-consultant teams.

In contrast to Werr and Styhre (2003), we claim that the main reason for the ambivalent accounts regarding the distribution of power in client-consultant teams is the lack of differentiation between the roles, the extent of involvement and the nature of power of different actors in consulting projects. This is in line with Garrat (1981: 97) who argued early on that there has been "confusion as to the relationship between the client (who commissioned the consultant) and the true owners of the problem (who were working on it and would be left to live with whatever results were obtained)". We take as a starting point for our discussion the roles and responsibilities of different groups of actors in consulting projects and describe actors' power relations vis-à-vis each other by focusing on their influence on problem solving and team interaction (Nikolova and Devinney 2005).

The aim of this paper is to shed light on the power relations within client-consultant teams thereby contributing to a more differentiated understanding of the power dynamics in consulting projects. We suggest that within client-consultant teams, actors make use of different influence tactics, the consequence of which is that there is no singular power base and direction. Rather, different types of power are at play and the outcome of this power struggle is not predetermined. In other words to what extent consultants and clients influence the outcome of consulting projects on a micro basis and, consequently, the production and dissemination of management practices on a macro basis, is not predetermined. Looking at the interactions between individual actors within concrete and specific consulting projects, we suggest that it is not ex ante clear who is the dominant actor and how this actor will influence the outcome of specific consulting projects.

Our approach is qualitative and semi-structured in nature. We conducted 19 in-depth interviews with consultants and 13 interviews with clients of consulting companies. The interviewed consultants worked for some of the most reputable international consulting firms as 
well as for some smaller, boutique consulting companies. Most of the participating clients came from large organizations. The majority of interviewed clients had either an executive or general management position within their organizations, with several of them occupying senior executive (C-suite) roles. Some of the interviewed clients and consultants had worked on consulting projects together, which represents a particularly interesting case of dyadic clientconsultant relationships for the analysis of the issue at hand. It is important to emphasize at this that none of the consultants we interviewed was solely dependent on one particular client company for their success within their consulting company.

This paper is structured as follows: In the first section, we introduce two types of power that we found to be relevant to the analysis of our empirical findings. Next, we describe our data sources and our methodology followed by an analysis of our findings. In the following section, we synthesize insights from our study with our theoretical discussion of power. At the end, we provide some concluding thoughts and practical implications.

\section{Defining power}

Political relations within client-consultant teams are relations of control or influence of the cultural production-i.e., problem solving—within client-consultant teams (Bunge 1979). In client-consulting teams, there are various categories of clients and consultants, each carrying with them different personal and organizational motivations, roles and responsibilities. As a result, different actors exercise different levels of control/influence over problem solving, turning the client-consultant interaction into a highly complex process (Kirsch and Eckert 1998).

As Sillince (2000) points out, any consideration of the role of power in a particular context depends on which of the many different perspectives on power one chooses. In this paper, we differentiate between two types of power-positional and rhetorical power-depending on the dominant source of influence over problem solving. These forms of power are particularly relevant in the work and interaction of committees, which, as “decision making fora” and a 
setting "for various kinds of communication” (Sillince 2000: 1126), possess many of the critical characteristics of client-consultant teams.

\section{Positional power}

Positional or episodic power is embedded in existing power relations and is based on resources, which can also include the control of decision-making processes (Hardy and Leiba-O’Sullivan 1998). It is “power over” (Clegg 1989: 215) initiated by self-interested actors (Lawrence et al. 2005), and is what causes individuals to act, or prevents them from acting via influence over the conditions under which they make decisions (Scott 2001). It is the result of previously institutionalized power relations (Clegg 1989; Sillince 2000) and, consequently, is given and stable at a particular point of time.

Positional power includes the use of both positive and negative sanctions of various kinds to influence the rational choices of others ensuring a particular behavior (Scott 2001). There are two types of positional power: (1) economic power that involves either coercion or rewards—it is the power to punish/prevent or to reward actors for undesirable/desirable outcomes based on such things as money, credit, access to employment or projects, etc.; and (2) legitimate powerpower grounded in the hierarchical position of individuals (Somech and Drach-Zahavy, 2002; Scott 2001). In organizations, positional power usually derives from the opportunities inherent in a person's position.

Positional power automatically reproduces existing configurations of resources, rules, and domination, as there is no challenge to existing discourses. The legitimacy of the resources it is based upon is sustained and institutionalized through the every day action of relevant actors. In other words, it is grounded in resource control through agents, whereas the nature of these resources is determined by existing relations and discourses between agents (Clegg 1989). Positional power is, therefore, similar to the notion of favorable "subject positions" as introduced by critical discourse analysis (Hardy and Phillips 2004). Subject positions imply that "some individuals, by virtue of their position in the discourse, will warrant a louder voice than others, 
while others may warrant no voice at all” (Hardy and Phillips 1999: 4, cited in Phillips 2003; Acroyd 2000). This implies that actors with positional power are in a favorable position to access and influence discourses—-through planning and setting the presence of other participants, control over modes of participation, turn-taking, agenda, topics or style (van Dijk 1993)—and to develop rhetorical power. At the same time, agents without positional power might be "silenced" (Brown and Coupland 2005; Newton 1996; Phillips 2003) so that they might have less chance to engage in processes of rhetorical power.

\section{Rhetorical power}

Rhetorical power is not predetermined by the possession or control of resources; rather, it emerges during actors’ interactions. It “operates through the offering and acceptance of reasons for acting in one way rather than another" (Scott 2001: 13) and "is the ability to make things become taken for granted” (Sillince 2000: 1128). For example, in advertising agencies power resides not in the possession of raw information about consumers and brands, but in "the way in which the meaning of that information is presented, understood and interpreted for the client” (Malefyt 2003: 153).

In it simplest form, rhetorical power rests upon a person's personality and attractiveness to others; i.e., in their charisma (Scott 2001). This type of power works independent of any arguments or discussions. In the critical literature on consulting, the influence and success of management gurus has been portrait mainly as the result of their charisma (Clark and Salaman 1998a; Jackson 2001). However, rhetorical power is rarely the mere result of charisma. More often it is the outcome of negotiations and translations of meanings and results in "interpretive dominance” (Meindl et al. 1994). In this process, “intrinsically appropriate reasons for action” are constructed and offered to others so that a particular course of action or a decision comes to be seen as cognitively, morally, or emotionally appropriate” (Scott 2001: 13). Such a persuasive influence is based on arguments, appeals, and reasons that cause individuals to believe that a particular decision or action is more appropriate than another (Scott 2001). 
Persuasion can operate through cognitive symbols_-ideas and representations that lead people to define situations in certain ways. This type of rhetorical power is also referred to as expert power-it arises from the attribution of expertise or knowledge to the influencing agent (Somech and Drach-Zahavy 2002; van Dijk 1993; Scott 2001). Rhetorical power can also operate through the building of value commitments to particular ideas or conditions. In such cases, individuals "defer to the views of those whom they regard as especially fitted to speak on behalf of these values", and so they build up commitment and trust to these agents (Scott 2001: 15). This type of rhetorical power is also called referent power-it arises when other actors identify themselves with the influencing actor (Somech and Drach-Zahavy 2002). In practice, these subtypes of rhetorical power are more often than not interwoven in some manner (Alvesson 2001; Scott 2001).

In any social system, rhetorical power is distributed among many actors; no single actor is able to determine completely a dominant set of meanings (Hardy and Phillips 2004). In other words, rhetorical power is never in the possession of a single actor. Instead, it is exercised by a number of actors and groups of actors (also Fox 2000). As a result, rhetorical power is never complete, leaving space for resistance through the production of counter meanings and interpretations. Furthermore, autonomous actors do not autonomously develop and hold rhetorical power; rather, existing practices and discourses work to advantage particular groups of actors, often without those groups being clearly connected to the establishment or maintenance of discourses and practices (Lawrence et al. 2005). This is a view of power that examines "how the field of force in which power is arranged has been fixed, coupled and constituted in such a way that, intentionally or not, certain 'nodal points' of practice are privileged in this unstable and shifting terrain” (Clegg 1989: 17). Such forms of power "tend to work in an ongoing, prosaic fashion, and they often do not appear to be forms of power” (Lawrence et al. 2005: 630; also Covaleski et al. 1998). This makes the development of rhetorical power an important strategic option for agents who try to establish a particular interpretation or discourse without being 
necessarily associated with that discourse on an ongoing basis. In other words, actors have the ability to legitimate and institutionalize particular meanings through their engagement in discourses and negotiations of meaning (Sillince 2000).

\section{Data sources and analysis}

The aim of our empirical study was to understand the perceptions and interpretations of consultants and clients with regard to influence in client-consultant teams. Data was collected through 19 interviews with consultants from different hierarchical levels and 13 interviews with clients. Although defined as semi-structured, the interviews each possessed a logical structure, as exhibited by the interview protocol given in the Appendix, which allowed us to keep some degree of control over the discussed themes and, at the same time, to tailor additional questions based on the direction of responses (Neuman, 2000). The interviews lasted from one to two hours each and focussed on consultant/client reflections on their role and responsibilities within client-consultant teams and their influence upon decision making, problem solving and interactional issues within the team. We also asked our interviewees to recount instances of successful and less successful consulting projects they have participated in and to share their insights and lessons learned. All interviews were taped and transcribed.

In the selection of our interview partners, we focussed on the general management, or strategic, consulting sub-sector. The majority of the consultants that we interviewed worked primarily in this area of consulting, ${ }^{2}$ and in our interviews with clients, we addressed their experience with strategic consulting. By focussing on strategic consulting, we were able to gain insights into rather large, complex consulting projects that involved several clients and consultants from different hierarchical levels and required an intensive interaction within the client-consultant team. These types of projects provide a rich ground for the analysis of power relations. Projects characterized by a one-one-interaction between a client and a consultant, such

\footnotetext{
2 In our interviews with consultants who mainly specialized in IT consulting we were addressing strategic IT projects.
} 
as the case of coaching, were not at the heart of our study. Table 1 and 2 summarize the main characteristics of our interviewees.

\section{Insert Tables 1 \& 2 About Here}

Three other important characteristics of our empirical data include:

1. We were able to interview seven clients and three consultants who participated in a major consulting project in one of the four major banks in Australia. The consulting project was sponsored by a Group Executive Manager, who was positioned one level below the CEO. The project involved a number of managers and consultants at different hierarchical levels of their respective organizations. The goal of the project was the preparation of a business case for a significant investment in a new IT system that would completely change the way business was done in this bank, at all levels. Due to the nature of this investment, there was considerable employee anxiety and resistance at all levels within the bank and one of the major tasks of the consultants was to work with a number of executive managers in different groups and divisions of the bank to help the project sponsor to overcome blockages and resistance. In addition, consultants had to work with lower level general and project managers in order to define all the issues to be addressed by the new system and answer questions, such as, how it will fit with the existing systems, how it will support the strategic direction of the company, how much resources were needed, etc. In other words, this was a very large strategic IT consulting project. The business case was accepted by the CEO, and the new IT system has been since implemented and is seen as a significant success.

This case of a dyadic client-consultant relation allowed us to compare clients’ and consultants' reflections on individual roles and responsibilities, team structure and influence tactics over decision making and problem solving, and how these influenced the outcome of the consulting project.

2. In our second and third dyadic case, we interviewed two high ranking clients from different organizations about their experience of working with consultancy D, as well as four 
consultants from different hierarchical levels. Combined, these six interviews gave us insights into the division of roles, responsibilities and influence on problem solving from both the client and the consultant side.

3. We interviewed two consultants positioned at different levels of consulting company B and consulting company $\mathrm{C}$, which offered further insights into the division of responsibilities and decision making authority from the consulting perspective.

We used these three groups of interviews as the foundation of our coding and data analysis. The rest of our interviewees all came from different client and consulting organizations. We used these interviews to discover whether there are any new, different or opposing insights with regard to our research question, which was not the case.

Our data analysis followed what Strauss and Corbin (1998) refer to as a "grounded theory framework”. Essentially, the grounded theory framework is an open-ended discovery of emerging themes. With the help of NVivo 7, the interviews were first open-coded in respect of client-consultant roles and responsibilities, their assessments of interaction dynamics, reasons for project successes and failures and lesson learned. Coding occurred iteratively in that initial themes were identified using the first groups of interviews as stated above. Additional transcripts were then examined using the initial themes. Last but not least, transcripts of dyadic clientconsultant relationships were analysed separately in order to allow for a direct comparison between views and perceptions of clients and consultants who have worked together and if a category appeared inaccurate or incomplete, additional themes were added or the cluster was reorganized. After the initial coding, a check-coding of the data took place three months later resulting in very high code-recode reliability. In a next step, we identified and explored overarching themes and patterns and developed our propositions related to power relations and influence, which lead to a more nuanced interpretation of power relations in client-consultant teams. 


\section{Case study findings}

\section{Project structure and formal roles and responsibilities}

In order to understand the nature the power dynamics within client-consultant teams, we first need to look at the specifics of the consulting project as an organizational form. This is necessary because, as Fiol suggests, "to understand the meaning of power in a given organizational context, we must be sensitive to the multiple dimensions of power and to the institutional rules that govern how power is played out in that context” (Fiol 1991: 550).

The extant literature has identified four broad roles required for accomplishing the work in any consulting project as: (1) sponsor/buyer of the project; (2) consulting partner; (3) project manager(s); and (4) clients and consultants who perform the work in the "work streams" (Hoffmann 1991; Nichols 2004; Maister 1982; Maister 2004). Our interviews confirmed that these actors have different roles and responsibilities and influence, to a different degree, the interaction within and the outcomes of consulting projects. In addition, we found that a committee made up of senior managers from the client organization, called the executive or steering committee (ExCo), plays a crucial role in major, strategic consulting projects with significant implications for the client company. Table 3 describe the characteristics and the roles and responsibilities of these actors.

\section{Insert Table 3 About Here}

To sum up, both the consulting partner and the sponsor are not involved in the day-to-day work of the consulting team but are responsible for scoping the project and making decisions with regard to possible problem solutions. The project managers on both sides are, in contrast, actively involved. Their main responsibilities are: (1) the management and coordination of clients and consultants in the work streams; (2) developing the story line on the basis of the generated data; and (3) communicating to the sponsor and the partner. The consulting and client team members in the work streams, who come from different hierarchical levels of their 
organizations, are the actors that are intensively involved in building the basis for the problemsolving process but are not directly involved in the actual development of the problem solution.

It is clear from our discussion so far that client-consultant teams are characterized by a clear hierarchy on both the client and the consultant side. As consultant 5 put it,

"So we all talk to the client, we just talk to different levels of the client. So the vicepresident [the partner] will talk to the CEO or the CIO or the CFO or one of the Cs; the manager will talk to one of the executive team or somebody who either reports to one of the Cs; and the consultants will talk to the guys underneath that”.

This is also confirmed by the fact that any conflicts or problems that cannot be resolved between the involved individuals are resolved by escalating the problem to the next level up in the client-consultant team, a procedure our interviewees called "escalating the issue”. As consultant 10 put it, “a good consultant [] if s/he can’t do it the informal way, then informally s/he goes to the next level above the one that frustrates you."

Several of our interview partners suggested that establishing such a clear division of roles and responsibilities, which predefines who communicates to whom and what alternative communication channels are there, who is responsible for what part of the work, who is responsible for what decisions and who is responsible for solving of any problems or disagreements, is a critical success factor in consulting projects. As client 2 suggested, “establishing the lines of authority in terms of we're working in these teams and these are the people working on these teams, is absolutely key”. Moreover, it is crucial that both the client and the consultant side are properly aligned; in other words, that the structure is replicated on both sides. With regard to this, client 2 added,

“what we’ve got here is a very formal structure that doesn't allow [] the ambiguity and miscommunication to arise. [] So if it's an issue it's an issue and it gets dealt with and there's a mechanism to deal with the problem. You only run into problems if people don't understand the channels of communication, or people purposefully go outside them.” 
Therefore, client-consultant teams can be described as temporary hierarchical social structures with strict rules and procedures set up and enforced by the project manager(s). Figure 1 illustrates the typical formal political structure of a large client-consultant team as described by our interviewees. In the following, we discuss in a detail how the interaction between clients and consultants unfolds in the context of this hierarchical relationship.

Insert Figure 1 About Here

\section{The interaction process between clients and consultants}

All of our respondents confirmed that close cooperation between clients and consultants at all levels of the team is very important for successful problem solving. Building an integrated team, so that all members can contribute to the process of data gathering and analysis is regarded as the best case scenario for consulting projects. However, looking more closely at these issues, our interviews revealed that there is a clear division in the roles of clients and consultants at different levels of the team and in their influence on the problem solving process. Furthermore, we found some subtle differences in the interpretations of clients and consultants regarding their interaction that gave us a more differentiated picture of power and influence in client-consultant teams.

\section{The client's story}

Our client interviews suggested that the view of the sponsor influences consultants in doing their analysis of the data, interpreting the data and developing recommendations. In this process, the sponsor can have more or less influence, depending on the issue at hand and the objective for engaging the consultants. For example, client 1, who had a rather critical view on consulting and only used consultants in situations when they needed some "smart people quickly", or what they referred to as "guns for hire”, summarized their view of the consulting job as follows:

"So they [the consultants] go and do the numbers, which you've done anyway, and they come back with a mighty volume which says 'sell'. And you say 'thank you very much, excellent work, it went the way I wanted it'. And of course the consultant knows that, 
probably, if they're any good, because when they ask the questions they'll figure out what the agenda is",

and added:

"they [the consultants] could advance 47 arguments as to why it should go blue but if I wanted green, it was going to go green.”

Client 12 suggested that they are a lot more involved in projects that are critically important. Such a project, they argued,

"really involves [] a lot more guidance, direction. Some of it is subtle because there is equal balance in it being an independent report that has to be seen to be independent, has to be-credibility (sic!) etc, of someone who is an expert, but also it's got to merge with the direction I'm heading in.”

Similarly, client 2 suggested,

"The good thing about being the customer of course is the customer is always right and generally I work with people who I trust, who will take that view and obviously that's my career and I've made those decisions on how to take it forward."

However, the same client also revealed that they had worked on consulting projects initiated by the CEO of their company, involving only the CEO, the Board of Directors and the consultants, where their contribution was solely to provide input into the problem solving process. In other words, often the client who engages the consultants and is directly responsible for the outcome of the project directs the problem solving process; members of the client team further down the hierarchy do not have the same authority and influence; they are not involved in the problem solving process itself. Our interviews showed that such a hierarchical division of authority within client-consultant teams was seen very critically by clients who were positioned in the middle of the hierarchy. The big banking case that we analysed is a very good example. Whereas the consulting project was seen as a big success by the senior clients, including the sponsor and the client project manager, three of the clients participating in the work streams expressed their dissatisfaction with the way the project was run. They suggested that due to the strict hierarchical division of roles and responsibilities within the client-consultant team, they did 
not feel that they were properly involved in the problem solving process and neither did they learn much from the consultants. Because decisions were made between the client and the consulting project managers and further up the hierarchy, these middle managers contributed only by supplying information and did not participate in the development of the recommendations. As client 4 put it, the project was a clear case of "a power play". These clients suggested that their counterparts from the consulting side were left "out of control” and were not really driven by the client project manager and the sponsor to add greater value to the project. In other words, those clients suggested that due to the hierarchical nature of the client-consultant team, communication, including critical discussions, took place primarily following a hierarchical, vertical direction and not horizontally, so there was less cooperation and knowledge transfer at their level of the client-consultant team, and opportunities for getting out more from the consultants were lost. Moreover, those members of the client team felt that they did not have any "power" or authority in their relationship with their consulting counterparts, which left some of them quite frustrated about the whole consulting project. As client 6 put it, their concerns were acknowledged by their counterparts from the consulting side; however,

“I wasn’t in a position at that point of time to challenge them because I wasn’t engaging the consultants; I was working with them on the project. [] the way of engagement didn't lead us to me expressing an opinion. They were doing a job. They’d been told to do a job. Someone else had said that's what they wanted them to do.”

Similarly, client 7 argued,

"In general they [the consultants] valued my contribution but there were times when they would obviously push their way more. I didn't feel that I had the last say, I felt that they did. We both worked for my manager who I guess hired them, and they were kind of like the experts []. S/he hired them to do this job.”

Client 12 described a very negative experience they had in a similar set of circumstances. Their immediate superior, who is the CEO, engaged consultants from a well respected consulting company to initiate changes in the organization. The CEO announced to his managers that the project was to be driven on the basis of intensive consultations with them. However, our 
interview partner pointed out that there was no cooperation and consultation with the consultants. The consultants prepared their recommendations, which involved very wide ranging changes within the organization, without any influence or consultation with clients’ managers. However, the CEO was not concerned with this obvious lack of cooperation and deemed the project a success. As client 12 put it, "because the outcomes are the 'correct ones' if you like, the findings that the CEO wanted to find, presumably, then it's all okay and it's all a success”.

To sum up, our interviews with clients revealed that the client who engages and pays the consultants has a very strong influence in the problem solving process. The more critical the project is, the more involved and directive the role of the sponsor. At the same time, such an intensive and directive interaction with the consultants can lead to problems further down the hierarchy of the client-consultant team if it leads to ignoring or not taking stronger into account the views and opinions of client team members.

\section{The consultants' story}

From the consultants' point of view, the consulting partner plays a critical role in the problem solving process. The partner translates

“a complex story into a series of discrete hypotheses about possible causes of that story of symptoms. Part of why you are doing is very subtly testing in your interaction those hypotheses with the [sponsor] so that you have an opportunity to iteratively, by the time you've finish the session, to have come away from that with a view as to how to start peeling apart these symptoms into causes and causes into solutions. [] If the partner's misheard or misinterpreted or counter-translated into action, you can't deliver a solution and therefore you lose the trust of the [sponsor]. [] therefore the skills of the partner in this model are to handle all of that upfront transition from hearing a problem described, to getting a team delivering solution, where the partner will continue throughout the relationship as the bridge between the team and the [sponsor].” (Consultant 6)

At the same time, consultants conceded that in this process they are guided by the view of the main client, which influences the way data is analysed and the development of recommendations: 
“...there is million ways to present things. [] So my analysis might be driven by the way the client is thinking, and I would expect that to happen. So I know that the client is thinking that this is the sort of direction they would need to go in. And this is where the client leads us. [] My analysis will probably get influenced by the client; I'd like to think no, but you don't know because I never do it twice and I always think that I'm doing the best job I can in the first place, but I would expect that potentially yes, why not? My analysis could be affected.” (Consultant 5)

Similarly, consultant 8 argued,

"sometimes there would be situations where we might not be presenting things in the way that we would have liked to. So not that we're presenting the wrong information, but the slant is different. And that's because at the end of the day that's our client and that's what they want. Then we have to listen to them at the senior levels, whereas at the more junior levels, we would do a bit more negotiating, and try to get them to understand what we're trying to achieve.”

One junior consultant, who was either less diplomatic or less careful, conceded: “we changed what we were doing to more suit what the client wanted, even though we didn't necessarily 100\% agree with it”.

However, consultants stressed that when they take the client's perspective into account in the data analysis process and in the development of their recommendations they do not compromise the quality of their work. From their perspective it is critical that there are no flaws and mistakes in the analysis; the analysis must be "right” technically:

“so it doesn't matter how you interpret the data a long as your interpretation is correct, it doesn't have any hole or a fallacy or a mistake in it, then what you're telling the client is correct and it's going to move them forward, and you give them a plan to do that.”

(Consultant 5)

Furthermore, consultants point out that the interpretative slant they take and the recommendations they develop should not jeopardize their integrity and reputation, and that their clients know and accept that. As client 2 put it, 
“if I just disregard what they're [the consultants] saying and say no, no it’s got to be done this time, then in that case it can't be done if it starts impacting their reputation []. They can’t accept that either and I won’t be a client.”

This shows that consultants need to find a balance between the needs of their immediate client and their own integrity and credibility. Several of the consultants that we interviewed described cases when they compromised their way of working and their views on what needed to be done in order to "make the client happy". The results were, however, an unhappy client in every case as these projects failed to the clients' ultimate objectives. Our interviewees admitted that it was a mistake to appease the client when the client's view was not right for the project. It is interesting to note that in none of these cases had the consultants received any follow-on work.

We further asked our interview partners to describe the process of finding the balance between their client's perspective on the issue at hand and their own view when they differ. Their responses show that consultants use a combination of subtle manipulation, rational reasoning and connecting to their clients on a personal level to achieve this balance. Consultant 11 described this process as follows:

"So you kind of have to strike a balance between giving what you think is the correct or the best answer or the best strategy or approach to the problem, but doing it in such a way that it doesn't undermine the kind of position and social structures of the people you are working for. [] It's a bit like turning a large ship. You kind of test the waters with how far the ideas can be pushed in certain direction, and encourage them to go a bit further in a certain direction, but you have to do it-everything has to be socialised very well. Surprises are really bad. Surprises are an absolute no-no.”

Consultant 10 differentiated between a formal process and an informal process, described as follows:

"[the formal process is] we do analysis, we present it to the hierarchy, we discuss, we make implementation plans []. Informal process is that you make people discover themselves what the answer is. So you meet over lunch, you give them the chance to read the draft of your report, you have some informal meetings about something else and then raise the sensitive part, or you have a sophisticated process where you actually make these guys think from the perspective of something else”. 
Consultant 5 pointed out the importance of developing a good and logical story:

"Everything we do is around stories. The stories include analysis; so what you do to convince somebody is to tell them about things that are specifically happening to that client and back it up with data, and that's how you convince people. [] And it's the story around the data that's the most important thing to tell because you have to convince people that what you're saying is right [].”

Similarly, consultant 7 refers to "the soft and hard approach". The soft approach is a "very empathetic and sympathetic approach" to people and their views; being a "true listener" ensuring that the consultant understands what people mean and why. This approach is complemented by a hard approach based on an analytical reasoning and the data.

In addition, our consulting interviewees pointed out that they always strive to have individuallevel discussions when they need to influence or persuade a critical client to change their perspective. Consultant 10 argued,

"[] it is much easier to influence somebody on a one by one level, on an informal level than in a group situation. Groups are egos, don’t want to lose face. So you identify those people [clients] who are problems, who need to be influenced early on. Try to work on them in all kinds of ways. Facts, emotion. Try to make them discover the answer. So they stand up and they take your idea and then you clap. What is better for a consultant than somebody who repeats after a month what you told them a month earlier. That's great, right? [] Now, if it doesn’t work—you are not at a situation everybody agrees. [] Then you work the hierarchy.”

In other words, if such a "soft” strategy based on persuasion and personal interaction does not succeed consultants revert to the formal strategy of escalating the problem up the hierarchy. A consultant in such a situation needs to identify the key individuals in the client company, the key decision makers, and to engage these people effectively.

A “soft” strategy is also adopted by consultants if decisions are made at ExCo level, which can be a particularly difficult situation given that the members of the ExCo often have opposing interests and agendas. In these circumstances, the partner and/or consulting project manager meets on a one-on-one basis with the members of the ExCo to talk them through their approach 
and recommendations. Several interviewees emphasized that there should be "no surprises" at the official ExCo meeting, because if this is the case, it is almost impossible to get the committee to agree on a certain direction or set of recommendations. As Consultant 9 put it, "the times where you haven't planned it [the ExCo presentation] properly, and you're presenting some information that is new, is the time where you've got potentially conflict.” Similarly, Consultant 1 argued that in one case, after they showed the ExCo pack of documents to the members of the committee, there was

“a lot of feedback and yeah a lot of suggestions, people didn’t like what we were saying. And so you'd just incorporate all that. So you don't actually at the steering committee show them the same pack, you show them a different pack. It's presented so it looks different, but it's all the same material. It's just now in a form where the story line works for the client. [] So you have to have the good facts and you have to have the right solution, but you also have to socialize it. And it's partly - that aspect of it is a bit of a political game in terms of making sure that everybody is on board with the ideas.” Or, as consultant 11 put it,

“It's just a standard kind of political process of buy-in and socialization before. It's not so much avoiding confrontation but it's managing so that there aren't threats to people's positions or authority in any meeting or decisions or results of work that you do.”

When we asked consultants, what happens if client team members further down the hierarchy disagree on a particular issue with regard to the analysis or developed recommendations and this disagreement cannot be solved at this level of interaction, they referred again to the formal procedure of "escalating the issue" up the team hierarchy. However, they also suggested that normally client team members participating in the work streams follow consultants' lead in their work on the project, or if there is an initial disagreement, it is quickly resolved. Consultant 1 added, "[I] tend to find that the client side often retreats a bit faster than the consulting side”, the reason being that consultants feel much more responsible for coming to a solution, whereas client team members just give in as they have their normal job to do as well. However, consultant 11 offered another possible view on this by arguing, 
“In many cases [of disagreement or differences in opinion] client team members I will ignore or overrule or just not worry about it []. Where it's a more senior person who disagrees [] all you can do is basically spend a fair bit of one on one time with that person; really understand exactly what their issues are around [].”

\section{Discussion}

In what follows we synthesize the insights from our empirical study and from research on the nature and role of power in organizations. As our empirical study uncovered, the actors with the most potential to influence the work of the client-consultant team are, due to their position, the sponsor of the project and the client project manager. Both of them have positional power. Our interviews showed that the sponsor, as well as the client project manager, regularly uses their positional power to influence the problem solving process in a desired direction. They either influence it directly, by restricting the solution alternatives that are discussed, or indirectly, by organizing the discussion, allowing or prohibiting specific speech acts, monitoring the agenda, setting and changing topics, and removing/transferring members of the team that would oppose their view. However, our study also revealed that consultants mobilize rhetorical power to counter balance the positional power of the sponsor/client project manager. We identified two sources of rhetorical power: one based on building up a personal relationship with the client and the other based on rational reasoning.

\section{The power of the sponsor/client project manager}

In client-consultant teams, the sponsor has legitimate power vis-à-vis other client team members based on their hierarchical position, which is mirrored in their authority to influence the team interaction in general, and problem solving in particular. As we saw in our interviews with clients, the sponsor has the authority to decide upon any issues arising within the client team including client's disagreement with the course of action taken by consultants.

Vis-à-vis the consultants, the sponsor has economic power, which is based on their authority to choose, engage and pay the consultants (see also Armbrüster 2006). Accordingly, consultants 
follow the sponsor's directions and develop recommendations that suit the needs and the perspective of the sponsor. This was confirmed by our interviewees when they argued that data can be interpreted in many ways, with consultants choosing an interpretation that leads to a problem solution that might not be "the technically most brilliant answer" but a very good answer that "will be generally accepted without being overly threatening" to the organization in general and the manager who engages the consultants in particular.

However, we also found that the sponsor knows that if they overrule consultants and put their credibility and reputation in jeopardy by asking them to sign on to recommendations that they do not support, they risk losing value from the project and increasing the likelihood that the consultants might withdraw or refuse to take on future projects. Consequently, in cases where perspectives clash, experienced managers and consultants have learned to work carefully, recognizing each other's agendas and interests and working to interpret/represent facts and data in a way that fits both their needs. It is an act of balance. As Pellegrinelli (2002: 352) points out, “consultants are influenced as well as influence during the course of an intervention.”

In reality, the sponsor often delegates part of their responsibility to the client project manager, who is then seen as the bearer of the sponsor's positional power. This is in line with Clegg and Courpasson (2004: 527) who argue, "the degree of perceived proximity of the project with the centre of the organization, the more or less innovative or strategic character of the project and the degree of control it is under, even the person behind the idea that drives the project [] all these will have an impact on the intensity and nature of authority of the project leader”.

\section{The power of the consultant}

Our interviews revealed that building up a personal, trust-based relationship with the client is seen as the most important success factor by both clients and consultants. Our client interviewees pointed out that once they develop trust in a particular consultant, they do not need to exercise the degree of tight control that is required in a first-time relationship. In other words, the client regards a trusted consultant as especially fitted “to speak on her/his behalf”. In this strategy, 
which involves socialization with the client, showing empathy and understanding, working with the client to understand their needs and to protect their position or authority, we see a case of referent power (Somech and Drach-Zahavy 2002); the type of power that results in clients identifying themselves, or their interests, with those of the their trusted consultant (also Bennis $(1966)^{3}$. This finding is in contrast to research that argues that power relations become irrelevant because clients and consultants develop trust to each other (Köppen 1999). In our view, developing trust to a client is a subtle power strategy used by consultants to enroll clients in their frames of reference (Nikolova and Devinney 2007).

Our study showed that the strategy based on building up the trust of the client was only applied when consultants deemed the client as 'important'. That was the case with regard to the project sponsor and the client project manager. In addition, consultants also used this strategy in order to "win over" (a) clients who had a critical position in the decision making process with regard to the project outcomes, i.e. crucial members of the ExCo, and (b) clients who were regarded as potential sponsors of future consulting projects.

The second influence strategy involves convincing the client by referring to the data and the data analysis. At the heart of this strategy was the consultants' claim of expertise and experience in choosing and using the proper methodology for data analysis and for developing recommendations. In other words, consultants were making use of their authority as experts to influence other actors (Somech and Drach-Zahavy 2002; van Dijk 1993; Scott 2001). Our study showed that this strategy, albeit targeted at all levels of clients, is more common in consultants' interactions with client team members participating in the work streams.

On the basis of these two forms of rhetorical power, consultants were offering a counter balance to the positional power of the sponsor/client project manager. As our study uncovered, the main goal for the consultants in this was to find the balance between satisfying the needs and

\footnotetext{
3 Bennis (1966: 168-168) refers to this type of power as to “value power”. A major shortcoming of Bennis' argument is that he does not discuss how consultants develop value power, and downplays the importance of expert power.
} 
the agenda of their immediate client and providing a good solution that will not compromise their own reputation and credibility.

Because rhetorical power works in a more subtle way than positional power, actors might not even be aware of the exercise of rhetorical power: by being involved in the interaction process, they can be slowly “enrolled” into a particular perspective. Thus, when there is no awareness of this process, there will be no resistance. As Mumby and Clair (1997: 184) argue, "the most effective use of power occurs when those with power are able to get those without power to interpret the world from the former's point of view”. This makes the development of rhetorical power an important strategic option for actors who want to influence particular situation or discourse in a subtle way, without to cause any resistance. Our study showed that consultants are aware of these properties of rhetorical power and use it to slowly and unobtrusively "enroll" managers into consultants’ perspective, which is confirmed by the following two quotes from a consultant and their client:

"What is better for a consultant than somebody who repeats after a month what you told them a month earlier. That's great, right?”

and

“A skilful consultant will get you to tell them what they have learnt, and they'll draw you into that by giving you little pieces of evidence. Let you draw your conclusion and let all the dots connect in your mind and you say, hey I've been thinking, why don't we look at that, and they've already thought about that, they've canvassed that thought in their mind, sown the seeds and reaped the response. That's a very skilled consultant and it happens. [] So if the consultant can convince you that this is your idea and they've helped you to reach that idea then I think that's a good outcome and [] in most instances [] conflict hasn’t arisen”.

\section{The dependent actor}

Our results indicated that client team members participating in the work streams often find themselves in an unfavorable position vis-à-vis both the sponsor/client project manager and the consultants. This invariably led to a feeling of being "silenced”. For example, our interviews 
with the general managers who participated in the big banking project showed that these managers did not feel properly involved in the project and that there was limited knowledge transfer from the consultants to them and their teams. Although consultants were making sure that the project manager and the sponsor were satisfied with their work, they did not put the same effort into meeting the needs of the other client team members. Those managers also argued that they did not have much "say” in the project. Most of our other client interviewees' had similar experiences.

That these client team members find themselves in the position of the dependent actor within client-consultant teams is problematic for several reasons. First, they can become frustrated about the project in general and the consultants in particular and can withhold information that is critical for the success of the project. Second, they often will not, or not fully, support the implementation of the consultants' recommendations. Third, in such projects, no knowledge transfer and learning takes place and, as a result, the organization does not get better value from the engagement of the consultants (Keegan and Turner 2001).

Ultimately, it is the client project manager's responsibility to ensure that client team members have a say in the project and are properly involved in the problem solving process. This requires that the sponsor/client project manager exercise a restraint in their direct influence on the problem solving process, as well as manage better the consultants. Consultants, too, have a responsibility in this process, as confirmed by the following quote of one of the consulting partners interviewed:

"Consultants have to help the client how to manage the consultant. [] The consultant at the senior level is managed well, at CEO level, but when s/he gets into the operations business unit of functional people, staff people, they get too much power, they get too much influence and the client has to manage the consultant better, but the consultant has got to tell the client how to do that, because they are often inexperienced in managing smart young consultants”.

\section{Conclusion}


By taking a differentiated look at the political structure of client-consultant teams and the power dynamics of client-consultant interactions, we were able to uncover a much more complex picture of power than hitherto discussed and to shed some light on the interdependent nature of power within client-consultant teams. As our study revealed, positional power, as expressed through the authority of the sponsor and the client project manager, influences significantly the outcome of consulting projects, accounts of which have been reported by previous research (e.g., Werr and Styhre 2003; Alvesson and Johansson 2002). However, our study also showed that consultants cannot be described as the client's marionettes; they mobilize subtler forms of rhetorical power to counter balance the positional power of the client senior managers. Earlier research has emphasized that the rhetoric and faddishness of consultant's language and concepts is the main source of consultant's rhetorical power (Alvesson 1993, 2001; Clark 1995; Kieser 1997, 2002; Clark and Salaman 1998a, b). In contrast, we argue that consultants use two major strategies to influence and enroll clients in their interpretive frames of reference. The first strategy is based on the skilful interpretation and presentation of facts. Rhetorical skills are only one ingredient in this strategy; consultants’ expertise and experience play a significant role in this strategy. The second strategy involves building personal relationships and trust with senior/critical clients, which results in clients developing commitment to particular consultants and their work and ideas. To what extent consultants' rhetorical power overpowers the sponsor's positional power in any one consulting project depends on the specifics of the project, such as its complexity, sensitivity and importance, the knowledge and experience of the client, as well as on the personalities of the sponsor and the consulting partner. In other words, to what extent consultants and clients influence the outcome of consulting projects on a micro basis, and consequently, the production and dissemination of management practices on a macro basis, is not predetermined. Our study further suggests that those members of the client team who participate in the work streams are exposed to both the positional power of their manager(s) and to the rhetorical power of the consultants. In the cases that we studied, these managers clearly 
represented the dependent actor in the relationship, which left them dissatisfied with the consulting projects where this was the case. Our study showed that consultants are aware that it is dangerous to embarrass/upset managers at lower levels of the hierarchy who might be potential clients and implementers. Consequently, consultants try to involve "critical” clients in a way that there is a "buy-in" for the consultants' recommendations.

Although our study provides rich data about the issue at hand, our findings are not generalizable due to the small sample. In addition, the present study concentrates on one segment of the consulting industry—strategic consulting—and it is an open question to what extent our findings are relevant for other types of consulting, and for smaller consulting projects. We would suggest that less strategic and less sensitive projects are characterized by less involvement/influence from the project sponsor and by more room for the consultants to frame the problem solving process, which was also indicated by some of our interviewees. Clearly, more research is needed to uncover differences in the power dynamics in different types of consulting projects. As this is an explorative study, we see its major contribution in providing first insights into the contested nature of power in client-consultant teams.

Another shortcoming of our study is that it relies on the perceptions and interpretations of our interview partners and the results might not show the whole picture of power dynamics in clientconsultant teams. Future research in this area will greatly profit from opportunities to observe client-consultant interaction for the duration of whole projects. This would also allow researchers to gain insights into the process of developing of interpretive dominance. ${ }^{4}$ In addition, more studies of dyadic client-consultant relationships are desirable.

Some practical implications of our discussion include: Managers in both client and consultant organizations need to pay special attention to the different types of power that are at work in consulting projects and how they influence the outcomes of these projects. In particular, the client's project managers should be aware of the discussed power dynamics when deciding upon

\footnotetext{
4 Bloomfield and Best (1992) provide a good example how this could be done.
} 
project goals and the extent of their involvement in consulting projects. As some of our interviews revealed, overpowering the client team members in one or another way can lead to less satisfactory project outcomes, as well as to implementation problems and hostility towards consultants among these client team members. On the other hand, we suggest that consultants need to be aware of three critical issues if their project is to be seen as successful. First, who is the "leading" client; the client who has the greatest input and the final say in the problem solving process? Second, what is to be done if this client's perspective/view on the issue does not lead to a problem solution that is the most effective under the given circumstances? And third, who needs to be "won over" in order for recommendations to be implemented successfully? At the same time, consultants need to be aware that unconditionally following client's views/preferences on a particular issue is not going to ensure their long-term success, neither with this particular client, nor with future clients. 


\section{References}

Abrahamson, E. (1996), Management fashion. Academy of Management Review 21(1): 254-285.

Ackroyd, S. (2000), Connecting organisations and societies: a realist analysis of structures.

Ackroyd, S. and Fleetwood, S. (eds.), Realist Perspectives on Management and Organisations. London: Routledge, 87-108.

Alvesson, M. (1993), Organizations as rhetoric: Knowledge-intensive firms and the struggle with ambiguity. Journal of Management Studies 30(6): 997-1015.

Alvesson, M. (2001), Knowledge work: Ambiguity, image and identity. Human Relations 54(7): 863-886.

Alvesson, M. and Johansson, A. (2002), Professionalism and Politics in Management

Consultancy Work. Clark T. and Fincham, R. (eds.), Critical Consulting. New Perspectives on the Management Advice Industry. Oxford: Blackwell Business, 228-246.

Armbrüster, T. (2006), The Economics and sociology of Management Consulting. Cambridge,

UK; New York: Cambrdige University Press.

Armbrüster, T. and Kieser, A. (2001), Unternehmensberatung-Analysen einer

Wachstumsbranche. Die Betriebswirtschaft, 61(6): 688-709.

Bennis, W. (1966), Changing Organizations: Essays on the Development and Evolution of Human Organization. New York: McGraw-Hill.

Bennis, W., Benne, K. and Chin, R. (1969), Collaboration and conflict. Bennis, W., Benne, K. and Chin, R. (eds.), The Planning of Change. London: Holt, Rinehart \& Winston, 147-153.

Bloomfield, B. And Best, A. (1992), Management consultants: systems development, power and the translation of problems. The Sociological Review 41: 533-560.

Boland, R. and Tenkasi, R. (1995), Perspective making and perspective taking in communities of knowing. Organization Science 6(4): 350-372.

Brown, A. and Coupland, C. (2005), Sounds of silence: Graduate trainees, hegemony and resistance. Organization Studies 26(7): 1049-1069.

Bunge, M. (1979), Treatise on Basic Philosophy Vol. 4. Ontology II: A World of Systems. Dordrecht: D. Reidel Publishing.

Clark, T. (1995) Managing Consultants. Consultancy as the Management of Impressions. Buckingham: Open University Press.

Clark, T. and Salaman, G. (1998a), Telling tales: Management gurus' narratives and the construction of managerial identity. Journal of Management Studies 35(2): 137-161.

Clark, T. and Salaman, G. (1998b), Creating the 'right' impression: Towards a dramaturgy of management consultancy. Service Industries Journal 18(1): 18-38.

Clegg, S. R. (1989) Frameworks of Power. London: Sage Publications. 
Clegg, S. and Courpasson, D. (2004), Political hybrids: Tocquevillean views on project organizations. Journal of Management Studies 41 (4): 523-545.

Coopey, J. and Burgoyne, J. (2000), Politics and organizational learning. Journal of Management Studies 37(6): 869-885.

Durrant, C. and Baxley D. (2004), Aligning business and technology strategy. Fombrun, C. and Nevins, M. (eds.), The Advice Business. Essential Tools and Models for Management Consulting, New Jersey: Pearson Prentice Hall, 288-314.

Ferdinand, J. (2004), Power, politics and state intervention in organizational learning. Management Learning 35(4): 435-450.

Fincham, R. (1999), The consultant-client relationship: Critical perspectives on the management of organizational change. Journal of Management Studies 36(3): 335-351.

Fiol, C. M. (1991), Seeing the empty spaces: Towards a more complex understanding of the meaning of power in organizations. Organization Studies 12(4): 547-566.

Flyvbjerg, B. (1998) Rationality and Power. Chicago: The University of Chicago Press.

Garratt, R. (1981), From expertise to contingency: Changes in the nature of consulting. Management Education and Development (Workshop) 12(2): 95-101.

Gunz, S. and Gunz, H. (2008), Ethical decision making and the employed lawyer. Journal of Business Ethics 81: 927-944.

Hardy, C. and Phillips, N. (2004), Discourse and power. Grant, D., Hardy, C., Oswick, C. and Putnam, L. (eds.), The SAGE Handbook of Organizational Discourse. London: Sage, 299-316. Hardy, C. and Leibia-O'Sullivan, S. (1998), The power behind empowerment: implications for research and practice. Human Relations 51(4): 451-83.

Haug, M. R. and Sussman, M. B. (1969), Professional autonomy and the revolt of the client. Social Problems 17(2): 153-161.

Hoffmann, W. (1991) Faktoren Erfolgreicher Unternehmensberatung. Wiesbaden: Gabler. Iding, H. (2000) Hinter den Kulissen der Organisationsberatung. Opladen: Leske + Budrich. Jackson, B. (2001) Management Gurus and Management Fashions. A Dramatistic Inquiry. New York: Routledge.

Keegan, A. and Turner, J. (2001), Quantity versus Quality in Project-based Learning. Practices. Management Learning 32(1): 77-98.

Kieser, A. (1997), Rhetoric and myth in management fashion. Organization 4(1): 49-74. Kieser, A. (2002), Managers as marionettes? Using fashion theories to explain the success of consultancies. Engwall, L. and Kipping, M. (eds), Management Consulting. Emergence and Dynamics of a Knowledge Industry. Oxford: Oxford University Press, 167-183. 
Kirsch, W. (1997) Wegweiser zur Konstruktion einer Evolutionären Theorie der Strategischen Führung, München: Kirsch.

Kirsch, W. and Eckert, N. (1998), Die Strategieberatung im Lichte einer evolutionären Theorie der strategischen Führung. Bamberger, I. (ed.), Strategische Unternehmensberatung. Konzeptionen-Prozesse-Methoden. Wiesbaden: Gabler.

Kubr, M. (1996), Management Consulting. A Guide to the Profession. Geneva: International Labour Office.

Lawrence, T., Mauws, M., Dyck, B. and Kleysen, R. (2005), The politics of organizational learning: Integrating power into the 4I framework. Academy of Management Review 30: 180-191.

Macey, J. and Sale, H. (2003), Observations on the role of commodification, independence, and governance in the accounting industry. Vilanova Law Review 48(4): 1167-1187.

Maister D. (2004), The anatomy of a consulting firm. Fombrun, C. and Nevins, M. (eds.), The Advice Business. Essential Tools and Models for Management Consulting, New Jersey: Pearson Prentice Hall, 17-32.

Maister, D. (1982), Balancing the professional service firm. Sloan Management Review 24(1): $15-29$.

Malefyt, T. (2003), Models, metaphors and client relations: The negotiated meanings of advertising. Malefyt, T. and Moeran, B. (eds), Advertising Cultures. Oxford: Berg, 139-163.

Marshall, N. and Rollinson, J. (2004), Maybe Bacon had a point: The politics of interpretation in collective sensemaking. British Journal of Management 15 (Special issue): S71-S86.

Meindl, J. R., Stubbart, C. and Porac, J. F. (1994), Cognition within and between organizations: Five key questions. Organization Science, 5(3): 289-293.

Mills, P. and Moshavi, D. (1999), Professional concern: Managing knowledge-based service relationships. International Journal of Service Industry Management 10(1): 43-67.

Mulligan, J. and Barber, P. (1998), The client-consultant relationship. Sadler, P. (ed.), Management Consultancy: A Handbook of Best Practice. London: Kogan Page, 66-85.

Mumby, D. and Clair, R. (1997), Organizational discourse. Van Dijk, T. (ed.), Discourse as Social Interaction. London: Sage, 181-205.

Neuman, W.L. (2000), Social Research Methods: Qualitative and Quantitative Approaches, 4th edn. Boston: Allyn \& Bacon.

Newton, T. (1996), Agency and discourse: Recruiting consultants in a life insurance company. Sociology 30(4): 717-723. 
Nichols, C. (2004), Managing projects. Fombrun, C. and Nevins, M. (eds.), The Advice

Business. Essential Tools and Models for Management Consulting, New Jersey: Pearson Prentice Hall, 153-177.

Nikolova, N. and Devinney, T. (2007), Building Community. Barry, D. and Hansen, H. (eds.),

New Approaches in Management and Organization, London: SAGE, 503-513.

Nikolova, N. and Devinney, T. (2005), The nature of power in client-consultant relationships.

Paper presented at the 2005 EGOS Colloquium, Berlin, June, 2.-5. 2005.

Nikolova, N. and Devinney, T. (2005), The nature and role of power in client-consultant relationships. Paper presented at the 2005 EGOS Colloquium, July 1-3 2004, Berlin, Germany.

Pellegrinelli, S. (2002), Managing the interplay and tensions of consulting interventions. The consultant-client relationship as mediation and reconciliation. The Journal of Management Development 21 (5/6): 343-365.

Phillips, N. (2003), Discourse or institution? Institutional theory and the challenge of critical discourse analysis. Westwood, R. and Clegg, S. (eds.), Debating Organization. PointCounterpoint in Organization Studies. Oxford: Blackwell Publishing, 220-231.

Sharma, A. (1997), Professional as agent: Knowledge asymmetry in agency exchange. Academy of Management Review 22(3): 758-798.

Sillince, J. (2000), Rhetorical power, accountability and conflict in committees: An argumentation approach. Journal of Management Studies 37(8): 1125-1156.

Scott, J. (2001) Power. Cambridge: Polity.

Somech, A. and Drach-Zahavy, A. (2002), Relative Power and influence strategy: The effects of agent/target organizational power on superiors' choices of influence strategies. Journal of Organizational Behavior 23: 167-179.

Sommerlatte, S. (2000) Lernorientierte Unternehmensberatung. Wiesbaden: Gabler.

Sturdy, A. (1997), The dialectics of consultancy. Critical Perspectives on Accounting 8: 511535.

Suddaby, R. and Greenwood, R. (2001), Colonizing knowledge: Commodification as a dynamic of jurisdictional expansion in professional service firms. Human Relations 54(7): 933-953.

Van Dijk, T. (1993), Principles of critical discourse analysis. Discourse \& Society 4(2): 249-283.

Werr, A. and Styhre, A. (2003), Management consultants—friend or foe? International Studies of Management and Organization 32 (4): 43-66. 
Table 1: List of interviewed consultants

\begin{tabular}{|c|c|c|}
\hline Interviewee & Interviewee’s experience & Characteristics of consultant company \\
\hline 1. $\quad$ Partner & 12 years & \multirow{5}{*}{$\begin{array}{l}\text { Consulting company A } \\
\text { Leading international strategy consulting } \\
\text { firm }\end{array}$} \\
\hline 2. Manager & 8 years & \\
\hline 3. Manager & $10+$ years & \\
\hline 4. Manager & $6+$ years & \\
\hline 5. Senior consultant & 18 months & \\
\hline 6. $\quad$ Director & $20+$ years & \multirow{2}{*}{$\begin{array}{l}\text { Consulting company B } \\
\text { Leading international strategy consulting } \\
\text { firm }\end{array}$} \\
\hline 7. Partner & $11+$ years & \\
\hline 8. Partner & $10+$ years & Consulting company C \\
\hline 9. Manager & 12 years & $\begin{array}{l}\text { Leading international strategy consulting } \\
\text { firm }\end{array}$ \\
\hline 10. Director & 20 years & \multirow{4}{*}{$\begin{array}{l}\text { Consulting company D } \\
\text { Leading Australian strategy consulting } \\
\text { firm }\end{array}$} \\
\hline 11. Director & $11+$ years & \\
\hline 12. Associate director & $5+$ years & \\
\hline 13. Business analyst & 1 year & \\
\hline 14. Director & $8+$ years & $\begin{array}{l}\text { Consulting company E } \\
\text { Mid-size Australian consulting company } \\
\text { specializing in health and safety, risk } \\
\text { management and change management }\end{array}$ \\
\hline $\begin{array}{l}\text { 15. Founder and } \\
\text { director }\end{array}$ & $8+$ years & $\begin{array}{l}\text { Consulting company F } \\
\text { Niche Australian consulting company } \\
\text { specializing in strategy and strategic IT } \\
\text { consulting }\end{array}$ \\
\hline 16. Manager & 5 years & $\begin{array}{l}\text { Consulting company G } \\
\text { Leading international consulting firm } \\
\text { specializing in IT consulting }\end{array}$ \\
\hline 17. Project manager & 7 years & $\begin{array}{l}\text { Consulting company } \mathrm{H} \\
\text { Mid size Australian consulting company } \\
\text { specializing in IT consulting }\end{array}$ \\
\hline 18. Director & 10 years & $\begin{array}{l}\text { Consulting company I } \\
\text { Sole consulting practitioner, } \\
\text { occasionally works in cooperation with } \\
\text { other consultants }\end{array}$ \\
\hline 19. Director & $20+$ years & $\begin{array}{l}\text { Consulting company J } \\
\text { Sole consulting practitioner, } \\
\text { occasionally works in cooperation with } \\
\text { other consultants }\end{array}$ \\
\hline
\end{tabular}


Table 2: List of interviewed clients

\begin{tabular}{|c|c|c|}
\hline Interviewee & Was the client of & Characteristics of client organization \\
\hline $\begin{array}{ll}\text { 1. } & \text { Group executive director } \\
\text { Level } 6\end{array}$ & & \\
\hline $\begin{array}{l}\text { 2. Executive general } \\
\text { manager; project director } \\
\text { Level } 5\end{array}$ & & \\
\hline 3. Executive manager Level & & \\
\hline 3 & & One of the four major banks in \\
\hline $\begin{array}{l}\text { 4. Executive manager Level } \\
\text { 3; former consultant }\end{array}$ & & Australia \\
\hline 5. General manager Level 2 & Consultant A & \\
\hline $\begin{array}{l}\text { 6. General manager Level 2; } \\
\text { former consultant }\end{array}$ & & \\
\hline $\begin{array}{l}\text { 7. Project manager; former } \\
\text { consultant }\end{array}$ & & \\
\hline 8. Chief development officer & Consultant D & A major mining company \\
\hline 9. Division CEO & Consultant D & Leading forest products company \\
\hline $\begin{array}{l}\text { 10. Project manager; former } \\
\text { consultant }\end{array}$ & $\mathrm{n} / \mathrm{a}$ & One of the major banks in Australia \\
\hline $\begin{array}{l}\text { 11. Head of marketing } \\
\text { development; former } \\
\text { consultant }\end{array}$ & $\mathrm{n} / \mathrm{a}$ & $\begin{array}{l}\text { Australia's largest sports and } \\
\text { entertainment ticketing company }\end{array}$ \\
\hline 12. Director of services & $\mathrm{n} / \mathrm{a}$ & The council of a major city \\
\hline 13. IT manager & $\mathrm{n} / \mathrm{a}$ & A major state government department \\
\hline
\end{tabular}

Note: The level indicates the position of the interviewee in the organizational hierarchy; Level 6 is one level underneath the CEO. 
Table 3: The actors in client-consultant teams and their roles and responsibilities

\begin{tabular}{|c|c|c|}
\hline Actor & Characteristics & Role and responsibilities \\
\hline \multirow[t]{2}{*}{$\begin{array}{l}\text { Consulting } \\
\text { partner }\end{array}$} & $\begin{array}{l}\text { Senior consultant with large } \\
\text { consulting experience and "own" } \\
\text { client portfolio }\end{array}$ & $\begin{array}{l}\text { Bears the final responsibility for client service; maintains an ongoing client relationship and regular } \\
\text { communications with the sponsor in order to understand and address client satisfaction (Durrant and } \\
\text { Baxley 2004) - the owner of client trust; is normally involved only on a part time basis in consulting } \\
\text { projects and overseas several projects at the same time; is responsible for the transition from hearing a } \\
\text { problem described by the sponsor to translating it into workable hypotheses, communicating the project } \\
\text { objectives to the rest of the client-consultant team and developing the story line; is the bridge between the } \\
\text { sponsor and the rest of the client-consultant team: }\end{array}$ \\
\hline & & $\begin{array}{l}\text { "The role of the partner in the GMC [general management consulting] space is very much to be both relationship } \\
\text { builder, owner of trust, interpreter of what the client wants; to translate a client problem which is often a symptom, } \\
\text { into a hypothesis around a cause and therefore into something which can be resolved by analysis." (Consultant } 6 \text { ) }\end{array}$ \\
\hline Client & Senior client manager/general & Is the sponsor's "right hand"-main communication channel between the sponsor and the consultants; \\
\hline
\end{tabular}

${ }^{5}$ Given that the ExCo represents members of the client organization who are affected by but not involved in the consulting project, an interesting and under researched area to look at is the role and involvement of the ExCo in consulting projects and how its decision making authority, or the lack of it, influences the outcome of consulting projects. A detailed discussion of this issue is out of scope here but we acknowledge its relevance and would like to thank Celeste Wilderom for stressing its significance. 


\begin{tabular}{|c|c|c|}
\hline Actor & Characteristics & Role and responsibilities \\
\hline $\begin{array}{l}\text { project } \\
\text { manager }\end{array}$ & manager & $\begin{array}{l}\text { responsible for building up the client team and for developing of the story line (with the consulting } \\
\text { project manager); can be involved more or less in running the project and managing of the team } \\
\text { members in the work streams; is often not involved in the project on a daily basis. }\end{array}$ \\
\hline \multirow[t]{5}{*}{$\begin{array}{l}\text { Consulting } \\
\text { project } \\
\text { manager }\end{array}$} & \multirow[t]{5}{*}{$\begin{array}{l}\text { Consulting manager (job manager; } \\
\text { principal, senior associate) }\end{array}$} & $\begin{array}{l}\text { Responsible for building up the consulting team, running the project and managing the team members } \\
\text { participating in the work streams (Hoffmann 1991; Nichols 2004) in order to get the deliverables } \\
\text { delivered. }\end{array}$ \\
\hline & & $\begin{array}{l}\text { Even though the client and consultant project manager work hand-in-hand (Durrant and Baxley 2004) and } \\
\text { are jointly accountable to deliver the work, in reality, the consulting project manager is responsible for all } \\
\text { details regarding the project, including the creation of the story line/possible recommendations, and } \\
\text { reports to the client project manager: }\end{array}$ \\
\hline & & $\begin{array}{l}\text { “The project leader/manager role is both guiding, structure and directing the team’s work and reviewing that on a } \\
\text { fairly close basis as well as managing the client’s management team as well [], and also managing their } \\
\text { expectations a lot. Making sure that there are no surprises”. (Consultant 2) }\end{array}$ \\
\hline & & $\begin{array}{l}\text { The job of the consulting project manager is seen as the most demanding and difficult job in consulting, } \\
\text { as s/he is, at one-and-the-same-time, the bridge between the rest of the team and the client project } \\
\text { manager, between the consulting partner and the consultants, as well as the main bridge and point of } \\
\text { contact between clients and consultants in the work streams: }\end{array}$ \\
\hline & & $\begin{array}{l}\text { "So under the partner is likely to be one job manager [project manager] and I think it's one of the toughest jobs in } \\
\text { consulting because the job manager has to take direction from the partner which is often fairly quick and not always } \\
\text { highly structured and to translate that into an analytical work program for maybe four or five reports to the senior } \\
\text { associates." (Consultant 6) }\end{array}$ \\
\hline \multirow{4}{*}{$\begin{array}{l}\text { Team } \\
\text { members } \\
\text { performing } \\
\text { the work in } \\
\text { the "work } \\
\text { streams" }\end{array}$} & \multirow{3}{*}{$\begin{array}{l}\text { Client team members represent the } \\
\text { main or primary clients - those } \\
\text { clients who “own” the problem for } \\
\text { which the consultants are brought } \\
\text { in; are the consultants' principal } \\
\text { collaborators and are usually } \\
\text { affected by the assignment. }\end{array}$} & $\begin{array}{l}\text { Engaged in data gathering and data analysis, hypothesis discussion, preparation of reports and } \\
\text { presentations. Not directly involved in decisions on problem solutions/recommendations: }\end{array}$ \\
\hline & & $\begin{array}{l}\text { "I think that's what's quite amusing in consultancy companies when people say 'I'm going to join this consultancy } \\
\text { and solve these problems'. In reality they collect the data and someone else solves the problems”. (Client 2) }\end{array}$ \\
\hline & & $\begin{array}{l}\text { On big projects, there can be several working groups or “work streams” each consisting of one } \\
\text { consultant and two or three clients and in most cases, the consultants responsible for each stream guide } \\
\text { the client team members with regard to the above activities. }\end{array}$ \\
\hline & $\begin{array}{l}\text { Consultants-associates and junior } \\
\text { consultants; on large projects can } \\
\text { include senior associates. }\end{array}$ & \\
\hline
\end{tabular}


Figure 1: Formal structure of a client-consultant team

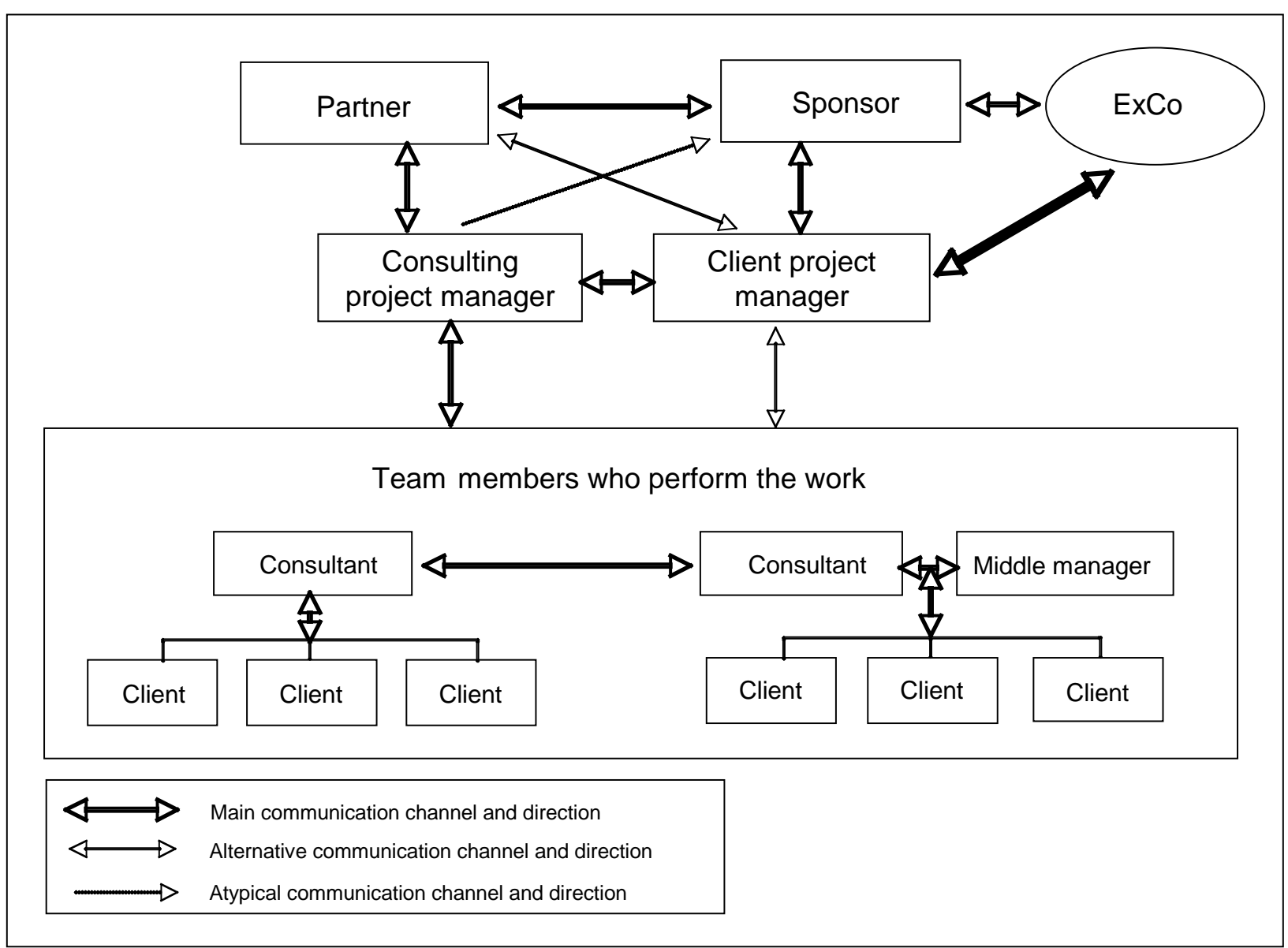


Appendix: Semi-structured interview question protocol. Note: some paraphrasing is used to make the questions more readable.

1. What is/was your position within your client/consulting company?

2. For consultants: How many years of work experience at this position do/did you have? For clients: How many years of experience do you have in working with consultants?

3. Please describe the typical project structure of consulting projects in which you have participated? Who was responsible for what? What were the different roles assigned to clients and consultants?

4. Please describe the first few meetings between clients and consultants. Discuss the main issues that are usually discussed in the first meetings.

5. Please describe your interaction with different members of the consultant/client team?

6. Please discuss problem solving during client-consultant interactions. What are your recollections of the process of problem solving?

7. Can you discuss situations when clients and consultants had different views on the problem they were discussing and its solution? How do you make sure that you talk about the same issue if there are disagreements or misunderstanding? How are these situations solved?

8. What if there is no consensus possible (everybody persists on their view)? How are such situations solved? Why? Who participates in this process?

9. Can you think of situations when there were disagreements within the client/consultant team? What happens in such cases?

10. Can you think of one very successful consulting project you have participated in? What were the main factors in your view that made it successful and why?

11. Can you think of one less successful or unsuccessful project? In what way was it less successful or unsuccessful? In your view, what were the main factors that made it less successful and why? 